\title{
Assessing the Effects of Aquatic Vegetation Composition on Waterbird Distribution and Richness in Natural Freshwater Lake of Malaysia
}

\author{
Abdoul Baset Hassen-Aboushiba \\ Zoology Department, Sebha University, Sebha, Libya
}

Email address:

abushibaa@yahoo.com

To cite this article:

Abdoul Baset Hassen-Aboushiba. Assessing the Effects of Aquatic Vegetation Composition on Waterbird Distribution and Richness in Natural Freshwater Lake of Malaysia. American Journal of Life Sciences. Vol. 3, No. 4, 2015, pp. 316-321. doi: 10.11648/j.ajls.20150304.20

\begin{abstract}
Aquatic vegetation structure and composition is a major driven factor which plays a significant role in waterbird foraging sites and habitat selection. Assessing the effects of aquatic vegetation composition on the distribution and richness of waterbird in a freshwater lake is a useful tool to understand the habitat requirement and preference of waterbird species for future better conservation and management. A total of 19 aquatic plants was recorded in the Paya Indah lake using $10 \times 10 \mathrm{~m}$ quadrant method. Eleocharis variegata (13.0\%), E. dulcis (12.0\%), Scirpus mucronatus (11.0\%), and Fimbristylis globulosa $(10.0 \%)$ were the most dominant aquatic plants which cover around $46.0 \%$ of the lake area. Likewise, a total of 1492 bird individuals represnting 24 waterbird species and 8 families was recorded through direct observation using 10 X50 binocular. Porphyrio porphyrio (17.02\%), Amaurornis phoenicurus (15.82\%), and Ardea purpurea (8.31\%) were three most common waterbird species in the study area. In contrast, three waterbird species, namely Hydrophasianus chirurgus (0.8\%), Tachybaptus ruficollis $(0.6 \%)$, and Gallirallus striatus $(0.54 \%)$ were the rarest i.e., recorded only a few individuals. Pearson's Correlation Coefficient test illustrated that aquatic vegetation species have strong positive correlationship (i.e., $r=0.9259, \mathrm{P}>$ 0.05 ) with waterbird species distribution and richness in the lake area. This showed that higher waterbird richness could be due to the diversity of aquatic vegetation species composition. Overall, the finding of this study highlighted that Paya Indah Lake is rich in aquatic vegetation structure and composition that had attracted a wide array of waterbird to perform various activities such as food, water, habitat and reproduce.
\end{abstract}

Keywords: Lake, Aquatic Vegetation, Waterbird, Richness, Distribution

\section{Introduction}

Wetlands are the most productive and diverse aquatic ecosystems, due to vegetation heterogeneity, unpredictable rainfall patterns, occurrence of different surrounded landscape and productivity. They characterized by shallow water overlying waterlogged soil, dominated by a variety of aquatic vegetation such as submerged, emergent, reedbeds, sedges, grasses and even shrubs and trees along the edges. The diversity of vegetation plays a significant role and effects on the distribution, diversity and richness of avian species especially wetland dependent bird species. It has been illustrated that the structure and composition of aquatic vegetation may vary dramatically even within the same habitat among the years (Winter et al. 2005).

Avian richness and diversity may vary across the different wetland habitats, depending on habitat structures, vegetation species composition and richness, occurrence of diversity of food resources, and adjacent surrounded landscapes. Bird species composition, richness and diversity are associated with aquatic vegetation structure and composition (Bersier and Meyer, 1995; Hurlbert, 2004) and occurrence of food resources. The heterogeneity of vegetation offer suitable loafing, foraging, nesting and refuge site that protect them from predators and harsh weather. Henning and Remsburg (2009) reported that higher avian richness may occur in wetland dominated by a wide array of aquatic vegetation and rich in food resources. Cunningham et al. (2008) and Barrett et al. (2003) illustrated that diversity of vegetation such as blocks of woodlands and scattered trees has an important interaction on bird species richness and diversity.

However, the role of the aquatic vegetation structure on avian richness and diversity is poorly documented in freshwater lakes. Detailed information on the effects of the 
vegetation structure and composition on the richness and diversity of avian species is still lacking. Therefore, this study was carried out to determine the effects of aquatic vegetation composition on waterbird distribution and richness in natural freshwater lakes of Malaysia to understand the importance of aquatic vegetation for waterbird species for better future conservation and management.

\section{Materials and Methods}

\subsection{Study Area}

The Paya Indah lake area is situated within $101^{\circ} 10^{\prime}$ to $101^{\circ} 50^{\prime}$ longitude and $2^{\circ} 50^{\prime}$ and $3^{\circ} 00^{\prime}$ latitude, covers an area of 450ha (Figure 1). This lake is dominated by diverse aquatic such as Water Chestnut, Bulrush, Fimbry, Needle Leaf Plant, Giant Bulrush, Lotus, Common Reed, Sedges, Cattail Plant, Joint Weed, Barnyard Grass etc.

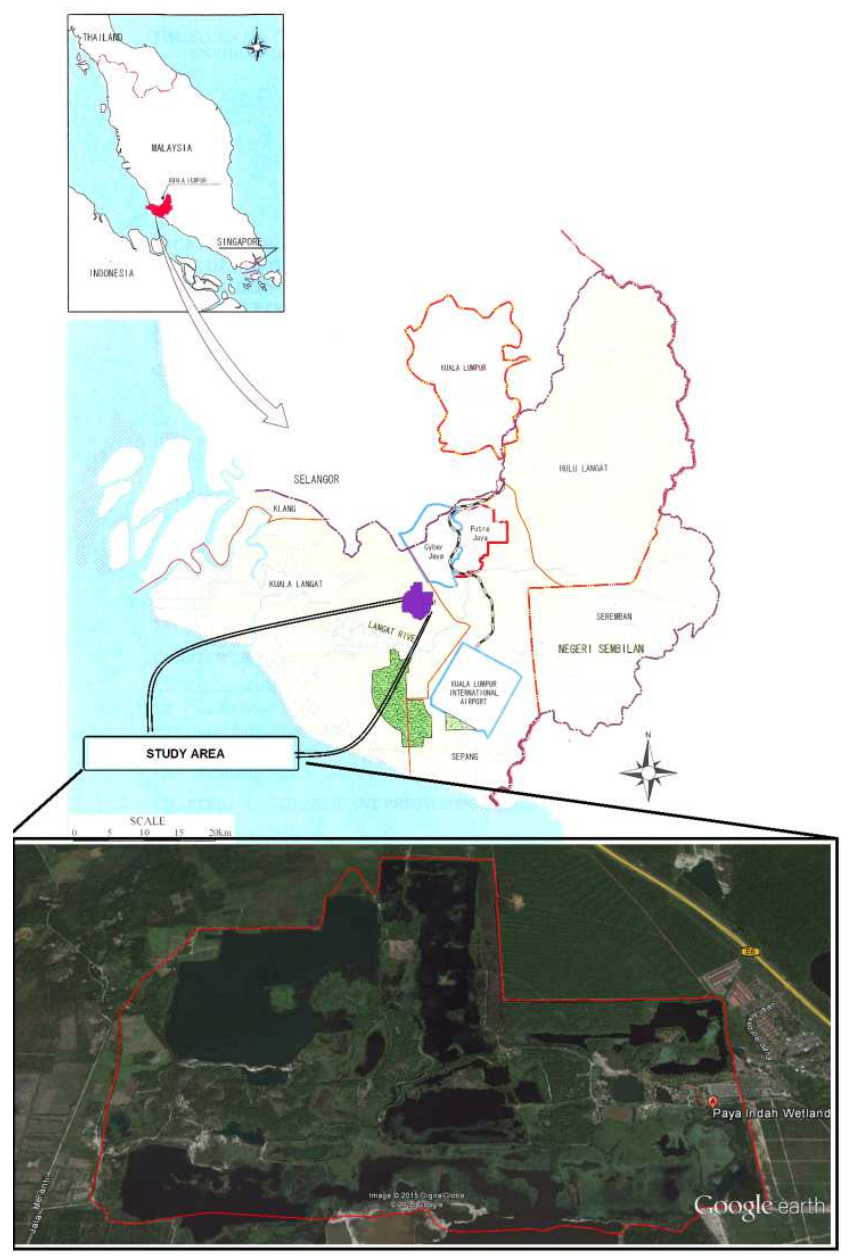

Figure 1. Location map of the study area.

\subsection{Aquatic Vegetation Composition Survey}

The aquatic vegetation composition of Paya Indah lake was examined using quadrant method $(10 \mathrm{~m} \times 10 \mathrm{~m})$. This method has been extensively employed to survey the variety of vegetation across the different habitats (Mumby et al., 1997; Fernandez-Alaez et al., 2002). Fifty quadrant plots were sampled along the edges and in shallow water to examine the aquatic vegetation composition in the lake area. In each sample plot, vegetation cover \% (i.e., the proportion of the water surface covered with aquatic vegetation), vegetation type (i.e., emerged and submerged vegetation, sedges, reeds, ferns and grasses). The aquatic vegetation variables in deep water were recorded using the visual estimation while the temperature and relative humidity were recorded using the Psychrometer. The methodology was followed as described by Isacch et al. (2005).

\subsection{Waterbird Survey}

Waterbird was surveyed at 50 point count stations simultaneously at the same sites where the aquatic vegetation composition and micro-climate variables were sampled. The presence of waterbird was recorded using binoculars (with 20X50 magnifications) from 0730 hours and ended at 1100 hours once in a month. Multiple visits (i.e., 12 visits) were made during the one year from November 2011 to January 2012. The methodology was followed by Kunz et al. (2007), Magrath et al. (2008) and Hamel et al. (2009).

\subsection{Data Analysis}

The relative abundance (\%) was determined using the following expression: $\mathrm{n} / \mathrm{N} \times 100$ where $\mathrm{n}$ is the number of a particular species and $\mathrm{N}$ is the total observations of detected species.

The effects of aquatic vegetation composition on waterbird distribution and richness were determined using Pearson's Correlation Coefficient in order to understand either aquatic vegetation composition may influence on the distribution and richness in the lake area employing following formula:

$$
r=\frac{\sum_{i=1}^{n}\left(X-M_{x}\right)\left(Y-M_{y}\right)}{\sqrt{\sum_{i=1}^{n}\left(X-M_{x}\right)^{2}} \sqrt{\sum_{i=1}^{n}\left(Y-M_{y}\right)^{2}}}
$$

Where; $\mathrm{X}=\mathrm{X}$ Values (waterbirds), $\mathrm{Y}=\mathrm{Y}$ Values (aquatic vegetation), $\mathrm{M}_{x}=$ Mean of $\mathrm{X}$ Values and $\mathrm{M}_{y}=$ Mean of $\mathrm{Y}$ Values

$\mathrm{X}-\mathrm{M}_{\mathrm{x}} \& \mathrm{Y}-\mathrm{M}_{\mathrm{y}}$ : Deviation scores,

$\left(\mathrm{X}-\mathrm{M}_{\mathrm{x}}\right)\left(\mathrm{Y}-\mathrm{M}_{\mathrm{y}}\right)^{2}$ : Deviation Squared,

$\left(X-M_{x}\right)\left(Y-M_{y}\right)$ : Product of Deviation Scores

\section{Results}

\subsection{Aquatic Vegetation Species Composition and Relative Abundance}

A total of 19 aquatic plants was sampled in the lake area using $10 \mathrm{~m} \times 10 \mathrm{~m}$ quadrant method at the Paya Indah lake. The results illustrated that Chinese Water Chestnut- 
Eleocharis variegata (13.0\%), followed by Groundchestnut/Water nut-E. dulcis $(12.0 \%)$ and Rice Field Bulrush-Scirpus mucronatus (11.0\%), and Globe FimbryFimbristylis globulosa $(10.0 \%)$ were four dominant aquatic plants which cover around $46.0 \%$ of the lake area. On the contrary, three aquatic plants, namely; Yefen-Fuirena umbellata, Knot Grass/Joint Weed-Polygonum barbatum, and Ludwig-Ludwigia spp., considered as a rare species (i.e., each covered only $1.0 \%$ ) were recorded in the study area (Table 1).

Table 1. List of aquatic plants with percentage, recorded in the lake area.

\begin{tabular}{|c|c|c|}
\hline Scientific Name & Common English Name & Percentage \\
\hline Eleocharis variegata & Chinese Water Chestnut & $13.0 \%$ \\
\hline Eleocharis dulcis & Ground-chestnut/Water nut & $12.0 \%$ \\
\hline Scirpus mucronatus & Bog Bulrush/Rice Field Bulrush & $11.0 \%$ \\
\hline Fimbristylis globulosa & Globe Fimbry & $10.0 \%$ \\
\hline Eriocaulon sexanglare & Needle Leaf Plant & $8.0 \%$ \\
\hline Scirpus grossus & Giant Bulrush/Greater Club Rush & $8.0 \%$ \\
\hline Lepironia articulata & Blue Rush/Twig Rush & $6.0 \%$ \\
\hline Rhynchospora corymbosa & Matamat & $5.0 \%$ \\
\hline Crinum defixum & Wild Garlic & $4.0 \%$ \\
\hline Phragmites karka & Common Reed/Giant Reed Grass & $4.0 \%$ \\
\hline Centella asiatica & Asiatic Penny-wort & $3.0 \%$ \\
\hline Cyperus halpan & Dwarf Papyrus Sedge & $3.0 \%$ \\
\hline Scleria sumatrensis & Nut rush & $3.0 \%$ \\
\hline Typha angustifolia & Cattail Plant & $2.0 \%$ \\
\hline Fuirena umbellata & Yefen & $1.0 \%$ \\
\hline Polygonum barbatum & Knot Grass/Joint Weed & $1.0 \%$ \\
\hline Ludwigia spp. & Ludwig & $1.0 \%$ \\
\hline
\end{tabular}

\subsection{Waterbird Species Composition With Relative Abundance}

A total of 1492 individuals, belongs to 24 waterbird species, representing 8 families were recorded through direct observation using 10X 50 binocular. Purple SwamphenPorphyrio porphyrio (17.02\%), White-breasted WaterhenAmaurornis phoenicurus (15.82\%), and Purple Heron-Ardea purpurea (8.31\%) were three most common waterbird species in the study area. In contrast, three waterbird species, namely Pheasant-tailed Jacana-Hydrophasianus chirurgus $(0.8 \%)$, Little Grebe-Tachybaptus ruficollis $(0.6 \%)$, and Slaty-breasted Crake-Gallirallus striatus $(0.54 \%)$ were the rarest in the study area (Table 2).

Table 2. List of waterbird species recorded in the lake area.

\begin{tabular}{lllll}
\hline Family Name & Common Name & Scientific Name & Point Count Method \\
\cline { 3 - 4 } & & & No of Observations & Percentage \\
\hline Rallidae & Purple Swamphen & Porphyrio porphyrio & 254 & 17.02 \\
Rallidae & White-breasted Waterhen & Amaurornis phoenicurus & 236 & 15.82 \\
Ardeidae & Purple Heron & Ardea purpurea & 124 & 8.31 \\
Charadriidae & Red-wattled Lapwing & Vanellus indicus & 104 & 6.97 \\
Ardeidae & Yellow Bittern & Ixobrychus sinensis & 98 & 6.57 \\
Rallidae & Common Moorhen & Gallinula chloropus & 97 & 6.50 \\
Anatidae & Cotton Pygmy Goose & Nettapus coromandelianus & 86 & 5.76 \\
Anatidae & Lesser Whistling Duck & Dendrocygna javanica & 84 & 3.63 \\
Rallidae & White-browed Crake & Porzana cinerea & 53 & 3.49 \\
Ardeidae & Grey Heron & Ardea cinerea & 52 & 2.95 \\
Ardeidae & Little Egret & Egretta garzetta & 44 & 2.41 \\
Alcidinidae & White-throated Kingfisher & Halcyon smyrnensis & 36 & 2.21 \\
Ardeidae & Little Heron & Butorides striatus & 1.88 \\
Ardeidae & Cinnamon Bittern & Ixobrychus cinnamoneus & 23 & 1.61 \\
Ardeidae & Great Egret & Chasmerodius albus & 24 & 1.54 \\
Scolopacidae & Common Sandpiper & Tringa hypoleucos & 23 & 1.47 \\
Rallidae & Water Cock & Gallicerx cinerea & 22 & 1.47 \\
Scolopacidae & Pintail Snipe & Gallinago stenura & 22 & 1.01 \\
Ardeidae & Schrenck's Bittern & Ixobrychus eurhythmus & 15 & 0.94 \\
Alcidinidae & Common Kingfisher & Alcedo atthis & 14 & 0.94 \\
Rallidae & Ballion's Crake & Porzana pusilla & 14 & 0.80 \\
Jacanidae & Pheasant-tailed Jacana & Hydrophasianus chirurgus & 12 & 0.60 \\
Podicipedidae & Little Grebe & Tachybaptus ruficollis & 9 & 0.54 \\
Rallidae & Slaty-breasted Crake & Gallirallus striatus & 8 & \\
& & Total & 1492 & \\
\hline
\end{tabular}




\subsection{Effects of Aquatic Vegetation Composition on Waterbird Distribution and Richness}

Pearson's Correlation Coefficient test illustrated that aquatic vegetation species have strong positive correlationship (i.e., $r=0.9259, P>0.05$ ) with waterbird species distribution and richness in the lake area. This showed that higher waterbird richness could be due to the diversity of aquatic vegetation species composition (Table 3 \& Figure 2).

Table 3. Test results of Pearson's Correlation Coefficient between aquatic vegetation composition and waterbird richness in the lake.

\begin{tabular}{llll}
\hline X Values & Y Values & X and Y Values & R Calculation \\
\hline$\sum=96.17$ & $\sum=102$ & $\mathrm{~N}=19$ & $\mathrm{r}=\sum(\mathrm{X}-\mathrm{My})(\mathrm{Y}-\mathrm{Mx}) / \sqrt{ }(\mathrm{SSx})(\mathrm{SSy})$ \\
Mean $=5.062$ & Mean $=5.368$ & $\sum(\mathrm{X}-\mathrm{Mx})(\mathrm{Y}-\mathrm{My})=296.459$ & $\mathrm{r}=296.459 / \sqrt{ }(379.124)(270.421)=0.9259$ \\
$\sum(\mathrm{X}-\mathrm{Mx}) 2=\mathrm{SSx}=379.124$ & $\sum(\mathrm{Y}-\mathrm{My}) 2=\mathrm{SSy}=270.421$ & & \\
\hline
\end{tabular}

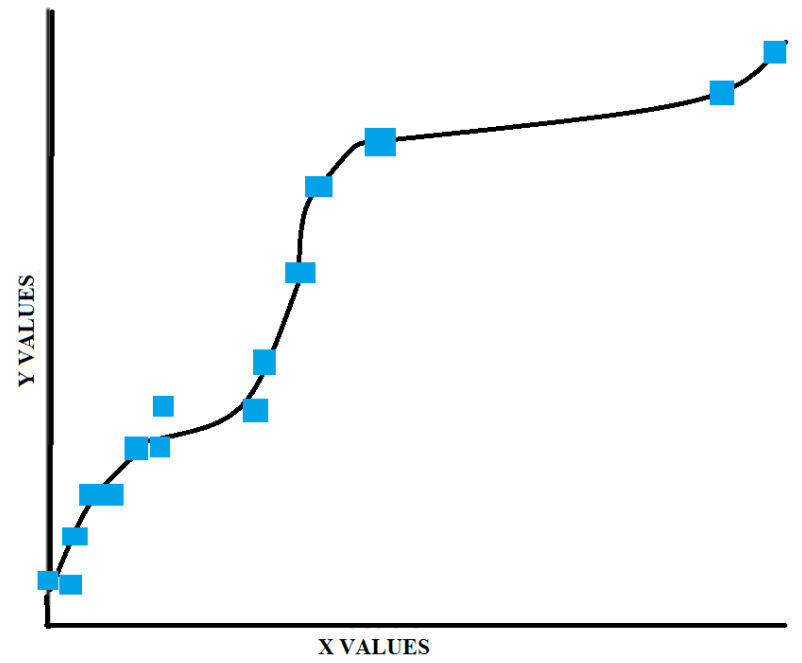

Figure 2. Biplot diagram of Pearson's Correlation Coefficient indicating the effects of aquatic vegetation composition on the distribution and richness of waterbird species in the lake habitat.

\section{Discussion}

Information on the aquatic vegetation species composition and habitat characteristics on the occurrence of waterbird richness is critically important for lake management and protection of the wide array of waterbird species inhabiting in a wide range of aquatic habitats. This detailed information will help in future conservation and management activities of waterbird species inhabited various aquatic habitats. The recording of 19 aquatic plant species and 24 waterbird species illustrated that Paya Indah Lake is rich in aquatic vegetation and waterbird species. This might be that, diversity of aquatic plants has created different microhabitats and rich in food resources that offer suitable habitats that had attracted a wide array of waterbird species to utilize this study area (Watson et al. 2004; Cousin and Phillips, 2008; Dami and Manu, 2008), in order to perform multiple activities i.e., foraging, perching, nesting, shelter and chick rearing sites.

The vegetation structure and floristic composition are a key factor that affected the habitat selection of the waterbirds, and indicated where and how they used the lake resources (Block and Brennan, 1993). Waterbird species positively correlated with lake area, habitat heterogeneity and vegetation cover percentage (Berg, 1997), i.e., variety of invertebrate communities occur in thick mats of aquatic vegetation (Bromham et al. 1999). Habitat variables, for instance, the aquatic vegetation cover percentage plays an important role in the distribution of prey and waterbird species in different lakes (Zharikov and Skilleter, 2002). Waterbird species may respond to aquatic vegetation structure and diversity that offers an adequate invertebrate food supply (Marshall and Cooper, 2004).

It was observed that waterbird distribution and richness may vary from lake to lake depending on the heterogeneity of vegetation structure and richness, foliage height, habitat size and ground vegetation cover (Gabbe et al., 2002; Goetz et al., 2007; Pidgeon et al., 2007; Brown, 2008). This might be that the variation in aquatic vegetation structure may affect the distribution and waterbird communities i.e., aquatic vegetation composition, richness, and cover percentage provide suitable foraging, roosting, and nesting sites for a wide array of waterbird species to fulfill their biological needs and increase their population (Abrams and Rodewald, 2002; Lee and Rotteberry, 2005; Augenfeld et al., 2008). Variation in vegetation attracted a variety of animals such as insects, reptiles and small mammals which is a major dietary component of different bird species. Hence it indicates that richness of food is a major factor that effect on the distribution and richness of waterbird species.

Furthermore, micro-climatic factors such as the temperature, rainfall, relative humidity and habitat variables, for instance, vegetation cover, had played important roles in the distribution of prey and bird species in the wetland ecosystem (Yates et al., 1993). In addition, other factors such as the weather (rainfall), social interactions (Erwin, 1983) and predators also played important roles in the distribution and habitat use of the wetland birds in the study area (Rivers, 2000; Zakaria et al., 2009). Strong and Sherry (2000) stated that food availability is one of the most key factors which effects on avian distribution, relative abundance and diversity across the different habitats. Habitat complexity may harbor higher resources such as food, perch, shelter and nest due to availability of different microhabitats (Hulbert, 2004). Hauser et al. (2006) reported that macro-fauna diversity and richness increased with an increase in habitat complexity. 


\section{Conclusion}

Aquatic vegetation structure and composition is a major driven factor which plays a significant role in waterbird foraging sites and habitat selection. The results of this study illustrated that aquatic vegetation composition influenced on the distribution and richness of waterbird species in the lake area. Furthermore, the results indicated that the aquatic vegetation species composition has strong positive correlationship on the distribution and richness of waterbird species in the lake area. Overall, the finding of this study highlighted that Paya Indah Lake is rich in aquatic vegetation structure and composition that had attracted a wide array of waterbird to perform various activities such as food, water, habitat and reproduce.

\section{References}

[1] Abrams, M.D. and A.D. Rodewald. 2002. Floristic and avian community structure: implications for regional changes in eastern forest composition. Forest Science, 48: 267-272.

[2] Augenfeld, K.H., S.B. Franklin and D.H. Snyder. 2008. Breeding bird communities of upland hardwood forest 12 years after shelterwood logging. Forest Ecology and Management, 225: 1271-1282.

[3] Barrett G., Silcock A., Barry S., Cunningham R. and Poulter R. 2003. New altlas of Autralian birds. Birds Australia, Melbourne.

[4] Berg, A. 1997. Diversity and abundance in relation to forest fragmentation, habitat quality and heterogeneity. Bird Study, 44: $355-366$.

[5] Bersier L.F. and Meyer D.R. 1995. Relationship between bird assemblages, vegetation structure and floristic composition of mosaic patches in riparian forests. Rev Ecol-Terre Vie., 50: $15-33$.

[6] Block, W.M. and Brennan, L.A. 1993. The habitat concept in ornithology: theory and applications. Current Ornithology, 11: $35-89$.

[7] Bromham, L., Cardillo, M., Bennett, A.F. and Elgar, M.A. 1999. Effects of stock grazing on the ground invertebrate fauna of woodland remnants. Australian Journal of Ecology, 24: 199-207.

[8] Brown, K. 2008. Effects of tree species, number of trees, basal area and understory vegetation on the abundance and diversity of avian species. Working Paper, Biological Station, University of Michigan (UMBS). Retrieved on $16^{\text {th }}$ June, 2013 at URL: http://deepblue.lib.umich.edu/bitstream/handle/2027.42/61500 / Brown_Katie_2008.pdf?sequence=1

[9] Cousin, J.A. and Phillips, R.D. 2008. Habitat complexity explains species-specific occupancy but not species richness in Western Australian woodland. Australian Journal of Zoology, 56(2): 95-102

[10] Cunningham R.B., Lindenmayer D.B., Crane M., Michael D., MacGregor C., Montague-Drake R. and Fischer J. 2008. The combined effects of remnant vegetation and tree planting on farmland birds. Conservation Biology, 22: 742-752.
[11] Dami, F.D. and Manu, S.A. 2008. The bird species of Pandam Wildlife Park and the surrounding farmlands. Science World Journal, 3(1): 7-11.

[12] Erwin, R.M. 1983. Feeding habitats of nesting wading birds: spatial use and social influences. Auk, 100: 96-970.

[13] Fernández-Alaez, M., Fernández-Alaez, C. and Rodríguez, S. 2002. Seasonal changes in biomass of charophytes in shallow lakes in the northwest of Spain. Aquatic Botany, 72: 335-348.

[14] Gabbe, A.P., S.K. Robinson, and J.D. Brawn. 2002. Treespecies preferences of foraging insectivorous birds: implications for floodplain forest restoration. Conservation Biology, 16: 462-470.

[15] Goetz, S., D. Steinberg, R. Dubayah and B. Blair. 2007. Laser remote sensing of canopy habitat heterogeneity as a predictor of bird species richness in an eastern temperate forest, USA. Remote Sensing of Environment, 108: 254-263.

[16] Hamel, N.J., Burger, A.E., Charleton, K., Davidson, P., Lee, S., Bertram, D.F. and Parrish, J.K. 2009. Bycatch and beached birds: assessing mortality impacts in coastal net fisheries using marine bird strandings. Marine Ornithology 37: 41-60.

[17] Hauser, A., Attril, M.J. and Cotton, P.A. 2006. Effects of habitat complexity on the diversity and abundance of macrofauna colonising artificial kelp holdfasts. Marine Ecology-Progress Series, 325: 93-100.

[18] Henning B.M. and Remsburg A.J. 2009. Lakeshore vegetation effects on avian and anuran populations. The American Midland Naturilist, 161 (1): 123-133.

[19] Hulbert, A.H. 2004. Species-energy relationships and habitat complexity in bird communities. Ecology Letters, 7: 714-720.

[20] Isacch, J.P., Maceria, N.O., Bo, M.S., Demaria, M.R. and Peluc, S. 2005. Bird-habitat relationship in semi-arid natural grasslands and exotic pastures in the west pampas of Argentina. Journal of Arid Environments, 62: 267-283.

[21] Kunz, T.H., E.B. Arnett. B.M. Cooper, W.P. Erickson, R.P. Larkin, T. Mabee, M.L. Morrison, M.D. Strickland, and J.M. Szewczak. 2007. Assessing impacts of wind energy development on nocturnally active birds and bats: a guidance document. Journal of Wildlife Management, 71: 2449-2486.

[22] Lee, P.-Yi and J.T. Rottenberry. 2005. Relationships between bird species and trees species assemblages in forested habitats of eastern North America. Journal of Biogeography, 32: 11391150 .

[23] Magrath, M., Weston, M., Olsen, P. and Antos, M. 2008. Survey Guidelines for Australia's Threatened Birds. Retrieved on $16^{\text {th }}$ June, 2013 at URL: http://www.environment.gov.au/epbc/publications/pubs/surve y-guidelines-birds.pdf

[24] Marshall, M.R. and Cooper, R.J. 2004. Territory Size of a Migratory Songbird in Response to Caterpillar Density and Foliage Structure. Ecology, 85:432-445.

[25] Mumby, P.J., Green, E.P., Edwards, A.J. and Clark, C.D. 1997. Measurement of seagrass standing crop using satellite and digital airborne remote sensing. Marine Ecology Progress Series, 159: 51-60.

[26] Rivers, J.W. 2000. Northern Harrier predation of White-faced Ibis. Wilson Bulletin, 112: 416-417. 
[27] Strong A.M. and T.W. Sherry 2000. Habitat-specific effects of food abundance on the condition of ovenbirds wintering in Jamaica. Journal of Animal Ecology, 69: 883-895.

[28] Watson, J.E.M., Whittaker, R.J. and Dawson, T.P. 2004. Habitat structure and proximity to forest edge affects the abundance and distribution of forest dependent birds in tropical coastal forests of southern Madgascar. Biological Conservation, 120: 311-327.

[29] Winter, M., Johnson, D.H. and Shaffer, J.A. 2005. Variability in vegetation effects on density and nesting success of grassland birds. Journal of Wildlife Management, 29 (1): 185197.
[30] Yates, M.G., Goss-Custard, J.D., McGrorty, S., Lakhani, K.H., Dit Durell, S.E.A.L.V., Clarke, R.T., Rispin, W.E., Moy, I., Yates, T. , Plant, R.A., and Frost, A.J. 1993. Sediment characteristics, invertebrate densities and shorebird densities on the inner banks of the Wash. Journal of Applied Ecology, 30: 599-614.

[31] Zakaria, M., Rajpar, M.N., and Sajap, S.A. 2009. Species diversity and feeding guilds of birds in Paya Indah Wetland Reserve, Peninsular Malaysia. International Journal of Zoological Research, 5(3): 86-100.

[32] Zharikov, Y. and Skilleter, G.A. 2002. Sex-specific intertidal habitat use in sub-tropically wintering Bar-tailed Godwits. Canadian Journal of Zoology, 80: 1918-1929. 